STUDLA HISTORYCZNE

R. LX, 2017, ₹. 2 (238), s. 47-56

\author{
Agnieszka Szwach
}

Jan Kochanowski University, Kielce

\title{
THE INJURIOUS AND CURATIVE POWERS OF HERBS: SHAKESPEARE IN HERB GARDENS
}

\begin{abstract}
For Galen, the best physician was the one who was able to treat his patients by means other than the knife, particularly through diet and drugs. The fact that basic knowledge of pharmacology was not required came under severe criticism in the late fifteenth and early sixteenth centuries. To remedy this situation, herb gardens were established at universities. Some physicians wrote voluminous new herbals based both on the close study of classical pharmacological works, observations and experiments. William Turner (1508-1568), Henry Lyte (15291607), John Gerard (1545-1650) and John Parkinson (1567-1650) were the essential figures who established English herbal tradition. This phenomenon was not entirely alien to Shakespeare. The study of tragedies, as presented in this paper, is sufficient to realise how numerous references to both healing and poisonous plants are made in Shakespearean plays.
\end{abstract}

Keywords: herbs, herbals, medicine, Renaissance, Shakespeare

Słowa kluczowe: zioła, zielniki, medycyna, renesans, Szekspir

The theory of medicine with its most distinctive ideas and the bulk of crucial, written sources did not originate in medieval western Europe although many of the twelfth and fifteenth century "institutional, social, and intellectual innovations" substantially contributed to early Renaissance medical culture (Siraisi, 1990, p. 1). Similarly to philosophical and psychological thought, it arose in ancient Greek and was later further developed in the Islamic world. This medical system began with approximately sixty treatises dating from the late fifth or early fourth century BC attributed to Hippocrates (460-370 BC) and known as the Hippocratic Corpus. They were further expanded by leading Alexandrian physicians and finally "corrected, amplified and remarkably sys- 
temised“ by Galen of Pergamum (Hoeniger, 1992, p. 71). Ancient Greeks and Galen (ca. 129-ca. 216 AD) in particular dominated the world of medicine for almost fourteen centuries

Over the course of his long and productive life, Galen not only made his name as an outstanding physician but also as a prolific author of numerous works on various topics ranging from medicine to literary criticism. His medical works, which included a great deal of his personal discoveries and experiences, reached canonical status already in antiquity as the fourth century medical encyclopaedia of Oribasius was, to substantial extent, founded on Galen's works. Up to the middle of the sixteenth century, medical students across Europe read his Ars Medica, used his anatomical texts or learned therapeutics from On the Therapeutic Method. However, Galen's text that is of greatest importance here is On the Powers (and Mixtures) of Simple Drugs (De Simplicium Medicamentorum [Temperamentis ac] Facultatibus). Vivian Nutton points to the fact that it is this particular treatise where Galen makes it clear what the qualities of the best physician are. Namely, it is the ability to treat "surgical conditions by means other than the knife, and particularly by diet and drugs" (2013, p. 240). Sabine Vogt (2008) claims further that Galen made one of the first attempts to collect effective remedies, systemise the known materia medica, and in particular to classify the powers and effects of drugs. His achievements were held in high esteem as late as the mid-nineteenth century when pharmacology embraced a new system of classification based on scientific findings of chemistry and, later in the twentieth century, cellular and molecular biology. He laboriously gathered and extensively presented his findings on the use of drugs in the eleven books of On the Powers (and Mixtures) of Simple Remedies (Drugs). The first five books of On the Powers sketch Galen's theory of the four humours as applied to pharmacology. The rest of them provide an intriguing catalogue of all sorts of drugs made with the use of, e.g. herbs, plants, stones, minerals and animal products. Books VI-VIII deal specifically with herbs and plants and the drugs made out of them are listed in alphabetical order. In total, Galen enumerates some 440 different plants and some 250 other substances as remedies at the same time offering a reader his detailed observations and practical information on their use. By the mid-sixth century, a synopsis of Oribasius' encyclopaedia and a selection of treatises by Hippocrates and Galen were additionally available in Latin.

Nancy Siraisi highlights that regular use of "certain common European plants as medicines began in antiquity and had a continuous history thereafter" (1992, p. 141). The knowledge of those plants, often used in cooking, which possessed medical powers, their choice and compounding in the proper proportions lay at the core of medical knowledge and gave foundations to medieval European pharmacy. In medieval Western Europe this simple "kitchen-garden" medicine was never only "empirical, local 
or folkloric" wisdom passed down from generation to generation by oral tradition, but was also informed by Greek medical written sources (Siraisi, 1992, p. 141).

Throughout the Middle Ages to the high Renaissance, these were the medical recipes which constituted the most popular form of medical writing. The eleventh century gave rise to the new medical literature that included numerous pharmacological terms. Those medical works were based on three essential elements: De material medica, Latin translation of Dioscorides' work; Galen's treatise on medical simples and lengthy sections on simple and compound medicines taken from the Arabic encyclopaedic works. Practitioners read those materials either in Latin or vernacular languages, in full or abbreviated versions, depending on their education and whether their "immediate purpose was academic or practical one" (Siraisi, 1992, p. 142).

At the same time urban development and concentration of medical communities in the cities "distanced some medical practitioners from personal familiarity with medical ingredients" (Siraisi, 1992, p. 146). In the early Middle Ages physicians prepared their own materia medica and continued to do so in rural areas. In the cities, however, things took a different course of action, tradesmen who specialised in compounding and selling medicinal substances appeared by the second half of the thirteenth century. Later, in the fourteenth, fifteenth and sixteenth centuries, it was common for individual physicians to be associated with particular pharmacies. Siraisi (1992) further elaborates on how practitioners cooperated with pharmacists consulting patients on the pharmacists' premises and prescribing medications available there. They frequently made use of medicaments that were obtainable on the flourishing trade in materia medica in the Mediterranean area. The actual content of those remedies was suspicious and its highly questionable that either physicians or pharmacists really knew what they were recommending to the patients. Giambattista Da Monte (1498-1551) one of Padua's most esteemed professors in medicine and the father of clinical teaching made it an issue to reveal the absurdities of materia medica market. In the early 1540s he exposed the forgery of Venetian pharmacies which claimed to be selling mummy parts. Such approach to compounding medicines that totally relied on pharmacists and did not require from physician even basic knowledge of pharmacology was severely criticised in late fifteenth and early sixteenth centuries.

Andreas Vesalius (1514-1564), as emphasised by Hoeniger (1992) was one of those critics who openly condemned the educational track of physicians, which in his time was devoid of pharmacological training. The problem was quickly addressed by the medical faculty of the University of Montpellier, where a course on pharmacy was introduced before 1550. For the sake of that enterprise, Guillaume Rondelet (1507-1566) enlarged the herb garden of Montpellier University. Similar steps were undertaken at the University of Basel under the close supervision of Caspar Bauhin (1560-1624), the 
eminent Swiss anatomist, physician and botanist. In 1589, Bauhin was appointed professor of Anatomy and Botany and thanks to his efforts a botanical garden was laid out in the University Campus (Ghosh, 2016, p. 161).

Karen Reeds' (1991) fine study Botany in Medieval and Renaissance Universities offers a thoughtful analysis of on-going transformations in the study of plants that took place at universities over the long sixteenth century. Reeds presents ample convincing evidence for her claim that by the early sixteenth century direct study of original texts by classical authors was favoured and efforts were made to reconcile names, descriptions and plants in nature. Consequently, this attitude lead to the proliferation of illustrated printed herbals and the growth of international community of scholars interested in botany. Physicians wrote voluminous new herbals based both on the close study of classical pharmacological works, observations and experiments. German physician and botanist Leonarht Fuchs (1501-1566) published in 1542, in Basel, his herbal book entitled De Historia Stirpium Commentarii Insignes. It contains 500 woodcut illustrations based on the actual plants, including over a hundred to be described for the first time. In 1544, Pietro Mattioli (1501-1577), who was educated at the University of Padua, published his comments on Dioscorides' Materia Medica to which he added descriptions of some plants with no medical use, thus, making a shift from the study of plants for curative purposes into a field of its own. Before turning to botany Flemish physician, Rembert Dodoens (1516/1517-1585), published works on cosmography and physiology but he made his name publishing Stirpium historiae pemptades sex sive libri XXX (1583) which is considered one of the foremost botanical works of the late sixteenth century. Clearly, before coming to England, the herbal "had an extensive life in print on the Continent" which was possible thanks to the preservation manuscripts of classical texts, mostly those by Dioscorides and Galen (Laroche, 2009, p. 5). William Turner (1508-1568), Henry Lyte (1529-1607), John Gerard (1545-1650) and John Parkinson (1567-1650) were the essential figures who established the "authoritative vernacular herbal tradition" in England (p. 5). These Elizabethan herbalists added a new quality to pharmacological studies as their publications not only abounded in detailed botanical description of both domestic and imported plants, but also provided instructions on their medical use.

The New Herball compiled by William Turner, an educated physician of some eminence and a notable preacher for the Reforming cause, was one of the first and most renowned of such works. It was published in three volumes from 1551 to 1568, made the first clear, systematic survey of English plants available to English practitioners and apothecaries, and greatly contributed to the improvement of their knowledge and training which "lagged so far behind" sophisticated training and medical practice offered at that time in northern Italy and the German lands (Addyman, 2014, p. 217). The 
Herball, based on Turner's own experience and scientific research, offered a detailed description of 144 plants, the names of which were given in alphabetical order in Latin, with English and Greek synonyms. It was additionally enriched with illustrations, mainly copies of those in Leonhard Fuchs's De historia stirpium (1542). Reading of the Preface to Part I, it is clear that the author himself was aware of the importance and usefulness of his enterprise. Turner openly claimed that the man who "took any paynes to set out any herbal" was as good to his country as any soldier shedding blood in its defence (Turner 1996 [1551], p. 25). In 1568, ten years after his death, William Turner was described by the writer William Harrison (1535-1593) as "the father of English physic". This praise would definitely have been appreciated by Turner, who referred to himself as a physician throughout his life even when a career change in 1551 led him to ministry within the English Church. To modern writers, Turner is first and foremost "the father of English botany" as his herbal was a significant step in development of botanical medicine (Addyman, 2014, p. 211).

Turner's New Herball was followed by H. Lyte's translation of Rembert Dodoens's Niewve herbal or historie of plants (1578) and, 30 years later, by another extremely successful publication The Herball or Generall Historie of Plantes by John Gerard, a surgeon and gardener for William Cecil, Lord of Burghley. The Herball in its "authoritative and literal weight" represented "metonymically a kind of medical authority" and was the most widely circulated botany book in English in the seventeenth century (Laroche, 2009, p. 1). In 1640, Theatrum Botanicum, the last great English herbal, was published by the apothecary John Parkinson. David Hoeniger (1992) underscores the fact that all English herbals share certain common features which include: thorough descriptions of plants and their habitat accompanied by eye-catching, realistic illustrations. Those descriptions are further followed by medical instructions which inform the reader about most medically useful parts of plants, illnesses and ailments that those plants can remedy and finally discuss application and dosage. As noticed by Laroche (2009), those splendid volumes, however, only reluctantly acknowledge women's practice in herbalism. Only Lady Margaret Hoby and Lady Grace Mildmay (1552-1620) are mentioned with regularity. This does not reflect at all the extent to which Elizabethan women were engaged in herbalism. The Perdita database currently includes 114 women's recipe books which mainly consist of medical recipes.

Stephen Greenblatt, in his numerous works of Shakespeare criticism, frequently stresses the extraordinary ability of the dramatist to absorb the surrounding reality into his works:

One of the prime characteristics of Shakespeare's art is the touch of the real. As with any other writer whose voice has long ago fallen silent and whose body has mouldered away, 
all that is left are words on a page, but even before a gifted actor makes Shakespeare's words come alive, those words contain the vivid presence of actual, lived experience. The poet who noticed that the hunted, trembling hare was "dew-bedabbled" or who linked his stained reputation to the "dyer's hand" (...) or who has a prince remember that his poor companion owns only two pairs of silk stockings (...) this artist was unusually open to the world and discovered the means to allow this world into his works. (Greenblatt, 2005, p. 13-14)

The world of herbs and herbalism was also "allowed" into the works of the Bard. The study of tragedies alone is sufficient to realise how numerous references to both healing and poisonous plants are made in Shakespearean plays.

In Romeo and Juliet we find Friar Laurence in his garden pondering upon the power of plants and herbs:

O mickle is the powerful grace that lies

In plants, herbs, stones, and their true qualities.

For naught so vile that on the earth doth live

But to the earth some special good doth give (2.3.11-14)

God created the variety of herbs and plants for the benefit of mankind. This straightforward view in fact encompasses the whole Christian tradition "which absorbed the classical theory of plant, animal, and mineral pharmacology, from Byzantine times through the Middle Ages down to 1600 and beyond" and echoes the basic philosophy of any sixteenth-century herbal (Hoeniger, 1992, p. 246). The anonymously published Grete herbal of 1525 informs the readers:

God in his goodness who is creator of all things has ordained, for the sustenance and health of his loving creature (mankind), who is made equally of the four elements and their qualities, and when any of these four [...] has more dominion, it constraints the body of man to great infirmities or diseases; for which the eternal God has given of his abundant grace virtues in all manner herbs to cure and heal all manner of sicknesses or infirmities [...] befalling him through the influence of these dominant elements and of the corruptions and venomous airs contrary to man's health. (qtd. in Hoeniger, 1992, p. 246-247)

William Turner in his New Herball, which was published much later, put the profession of the physician far above any other "noble and excellent artes \& sciences". He found the knowledge of "herbs, shrubbes and trees" an essential thing for a physician. Furthermore, such knowledge was sanctioned by the Bible. In the prologue, Turner 
mentions that he did not recall reading any "commendations" of grammar, logic or philosophy in the holy scripture but he remembers reading "among commendations and prayers of king Salomon" that the Israelite king had deep knowledge of herbs and plants and 'disputed wisely of them." (1996 [1551], p. 25). Over forty years later John Gerard reiterated most of those arguments in his herbal. No other creation of God "provoked men studies more as plants" and all of that done for the worthy cause of finding medical cures. The world is covered with plants "as with a robe of imbroidered work", they appeal to all our senses but what matters most are their curative powers that "no confection of Apothecaries can equall" (Gerard, 1597, p. 8). Again, the example of King Salomon is used to give the study of plants a divine blessing.

Among the great variety of plants that God bestowed upon men there are also those which have both curative and poisonous powers. In Shakespeare we can learn that, further on, from Friar Laurence's speech delivered in his herb garden:

Within the infant rind of this weak flower

Poison hath residence, and medicine power. (2.3.19-20)

Friar Laurence knows how to tackle poisonous qualities of plants. He describes in details the action of the sleeping potion that he gives to Juliet. It will make that each part of Juliet's body:

deprived of supple government,

Shall, stiff and stark and cold, appear like death:

And in this borrow'd likeness of shrunk death

Thou shalt continue two and forty hours,

And then awake as from pleasant sleep. (4.1.102-106)

However, the Friar does not disclose the name of plant that was used to prepare the potion. Throughout Middle Ages and Renaissance, three plants were mainly used for their narcotic properties: mandrake or mandragora, opium and hemlock. The first one was regarded as the safest and had been widely recommended by the ancient and Arab physicians. In the sixteenth century it was used as an anaesthetic during amputations (Hoeniger, 1992, p. 252). The legend of the mandragora plant recorded in the herbal of Apuleius asserted that when pulled out the mandrake would scream in such a high-pitched human voice that it could kill whoever was trying to get it out of ground. Hence a special procedure was devised which advised to tie a dog to a mandrake root and tempt it with meat from a reasonable distance (Siraisi, 1992, p. 151). As Hoeniger (1992) points out that legend is also referred to in the text of Romeo and Juliet. 
Juliet overwhelmed by the doubts, fears that the potion might be deadly or to the contrary it might stop working too early:
Alack, alack, is it not like that I,
So early waking, what with loathsome smells,
And shrieks like mandrakes' torn out of the earth
That living mortals, hearing them, run mad:
$\mathrm{O}$, if I wake, shall I not be distraught
Environed with these hideous fears? (4.3.46-50)

The narcotic qualities of mandragora are also alluded to in Othello, where Iago with satisfaction concludes that "Not poppy, nor mandragora,/ Nor all the drowsy syrups of the world" will give the Venetian general "sweet sleep" after he stirred up (3.3.327, 329).

The root of hemlock that the witches of Macbeth place into their bubbling cauldron is not only poisonous in its own right but is additionally "digged in the dark", making it a far more evil and deadly ingredient (4.1.25). Reynolds and Sawyer observe the Elizabethans had one basic principle that ruled the collection of medical herbs and plants: those gathered in the light of moon had healing powers and those picked at night were "death-dealing" (1959, p.515). Shakespeare, as demonstrated by Reynolds and Sawyer (1959), discloses his awareness of the lethal power of the night and beneficial effect of the moonlight in Hamlet. In the players' scene, the duke murders the king by pouring poisonous liquid made of "midnight weeds" (3.2.268) into a sleeping's man ear. ${ }^{1}$ While Laertes, before his duel with Hamlet, explains that the wounds inflicted by his poison-dipped sword will not be healed by "all the simples that have virtue/Under the moon" (4.7.145).

The witches add one more deadly plant to their hideous gruel, namely "slips of yew" (4.1.27). The yew tree was frequently planted in English graveyards and it was widely believed that all its parts were poisonous. Its wood was also used for the bows handled by archers. Thus, it has three-fold association with death. Shakespeare could have learned from the popular sixteenth-century encyclopaedia compiled by Stephen Batman and published in 1582 that:

Yew is altogether venomous and against man's nature. The birdes that eate the redde berryes eyther dye, or cast their fethers. (qtd. in Hoeniger, 1992, p. 254)

\footnotetext{
Upon Old Hamlet death was brought by "cursed hebenon" (1.5.62). Hoeniger thoroughly explains that the word "hebenon" is probably derived from Latin bebenus or ebenus meaning ebony, the resin of whose bark is narcotic (1992, p. 254).
} 
Not only poisonous qualities of herbs and plants are alluded to in Shakespeare's tragedies. In Macbeth, for instance, the dramatist refers to rhubarb as having the quality to purge the body of evil humours. Macbeth while frantically preparing for the final battle, begs the Doctor:

If thou couldst, doctor cast

The water of my land, find her disease,

And purge it to a sound and pristine health,

I would applaud thee to the very echo

That should applaud again .....

What rhubarb, senna or what purgative drug,

Would scour these English hence? (5.3.50-56)

In Elizabethan times, rhubarb was one of the most common purgative drugs; it was not prepared from the familiar kitchen plant of today but rather from the dried root of a plant of the same family and was used particularly against choler (Hoeniger, 1992, p. 248).

Most of the sixteenth-century herbals give countless medical uses of garden rue. It is good for swellings, biting of mad dogs, sore throat, toothache. It could protect one from being infected by sick people and even from plague. Rue, was also known as an herb of grace because it symbolised repentance, which was given to people by God's grace. In this sense it is mentioned in Hamlet and Richard II. But it was also called the herb grace or herb of grace because of its medicinal power or "virtue" derived from God, who created the plant for the benefit of animals and man.

The wealth and depth of Renaissance herbal writing and appropriation of this knowledge into literature and theatre for good shaped the Elizabethan society's attitude to plants. It appreciated the beauty of plants but was much more interested in medical uses and the diseases that herbs could remedy.

\section{Bibliography}

\section{Primary sources:}

Gerarde, J. (1597), The Herball or Generall Historie of Plantes, London: John Norton.

Chapman, G. and Tweddle, M. (eds.) (1996 [1551]), William Turner: A New Herball, Cambridge: Cambridge University Press.

A.T., (1596), A Rich Store-House or Treasury for the Diseased.

Wells, S., Taylor, Gary., Jowett, J. and Montgomery, W. (eds.) (2005), The Oxford Shakespeare: The

Complete Works. Oxford: Oxford University Press. 


\section{Secondary sources:}

Addyman, M. (2014). William Turner: A Milestone in Botanical Medicine. In S. Francia \& A. Stobart (eds.), Critical Approaches to the History of Western Herbal Medicine. London-Sydney: Bloomsbury.

Francia, S. \& Stobart, A. (eds.) (2014). Critical Approaches to the History of Western Herbal Medicine. London-Sydney: Bloomsbury.

Galen, (2011). De simplicium medicamentorum temperamentis ac facultatibus lib. VII-VIII. In G.K. Kühn (ed.). Claudii Galenii Opera Omnia. Cambridge: Cambridge University Press.

Gill, M.K. (ed.) (2017). The 100 Most Influential Medical Pioneers of All Time. New York: Britannica Educational Publishing in association with Rosen Educational Services.

Ghosh, S. (2016). Caspar Bauhin (1560-1624): Swiss Anatomist and Reformer of Anatomical Nomenclature. IJAE, vol. 121, no. 2, pp. 159-164. http://dx.doi.org/10.13128/IJAE-18489.

Greenblatt, S. (2005). Will in the World. How Shakespeare Became Shakespeare. London: Pimlico.

Hankinson, J.R. (ed.) (2008), The Cambridge Companion to Galen. Cambridge: Cambridge University Press. https:dx.doi.org/10.1017/CCOL9780521819541.

Hankinson, J.R. (2008). The Man and His Work. In J.R. Hankinson (ed.), The Cambridge Companion to Galen (pp. 1-33). Cambridge: Cambridge University Press. https://dx.doi.org/10.1017/ CCOL9780521819541.001.

Hoeniger, F.D. (1992). Medicine and Shakespeare in the English Renaissance. Newark: University of Delaware Press; London-Toronto: Associated University Press.

Laroche, R. (2009). Medical Authority and Englishwomen's Herbal Texts, 1550-1650. Farnham-Burlington: Ashgate.

Nutton, V. (2013). Ancient Medicine. London-New York: Routledge.

Reeds, K. (1991). Botany in Medieval and Renaissance Universities. New York: Garland.

Reynolds, A. \& Sawyer, P. (1959). Folk Medicine and the Four Fairies of A Midsummer-Night's Dream. Shakespeare Quarterly, vol. 10, no. 4, pp. 513-521.

Siraisi, N. (1992). The Medieval and Early Renaissance Medicine. Chicago: The University of Chicago Press.

Vogt, S. (2008). Drugs and Pharmacology. In J.R. Hankinson (ed.). The Cambridge Companion to Galen (pp. 304-322). Cambridge: Cambridge University Press. https://dx.doi.org/10.1017/ CCOL9780521819541.012. 